\title{
Mucoadhesive microemulsion of ibuprofen: design and evaluation for brain targeting efficiency through intranasal route
}

\author{
Surjyanarayan Mandal ${ }^{1, *}$, Snigdha Das Mandal ${ }^{2}$, Krishna Chuttani ${ }^{3}$, Bharat Bhushan Subudhi ${ }^{1}$
}

${ }^{1}$ School of Pharmaceutical Sciences, Siksha 'O'Anusandhan University, Khandagiri Square, Bhubaneswar, Orissa, India, ${ }^{2}$ Department of Pharmacology, Parul Institute of Pharmacy and Research, Vadodara, Gujarat, India, ${ }^{3}$ Division of Cyclotron \& Radiopharmaceutical Sciences, Institute of Nuclear Medicine and Allied Sciences (INMAS), DRDO, Delhi, India

\footnotetext{
*Correspondence: Surjyanarayan Mandal. Research Scholar. School of Pharmaceutical Sciences, Siksha 'O' Anusandhan University - Khandagiri Square - Bhubaneswar, Orissa, India. E-mail: surjya05n08@mail.com
}

\begin{abstract}
This study aimed at designing mucoadhesive microemulsion gel to enhance the brain uptake of Ibuprofen through intranasal route. Ibuprofen loaded mucoadhesive microemulsion (MMEI) was developed by incorporating polycarbophil as mucoadhesive polymer into Capmul MCM based optimal microemulsion (MEI) and was subjected to characterization, stability, mucoadhesion and naso-ciliotoxicity study. Brain uptake of ibuprofen via nasal route was studied by performing biodistribution study in Swiss albino rats. MEI was found to be transparent, stable and non ciliotoxic with $66.29 \pm 4.15 \mathrm{~nm},-20.9 \pm 3.98 \mathrm{mV}$ and $98.66 \pm 1.01 \%$ as average globule size, zeta potential and drug content respectively. Transmission Electron Microscopy (TEM) study revealed the narrow globule size distribution of MEI. Following single intranasal administration of MMEI and MEI at a dose of $2.86 \mathrm{mg} / \mathrm{kg}$, uptake of ibuprofen in the olfactory bulb was around 3.0 and 1.7 folds compared with intravenous injection of ibuprofen solution (IDS). The ratios of AUC in brain tissues to that in plasma obtained after nasal administration of MMEI were significantly higher than those after intravenous administration of IDS. Findings of the present investigation revealed that the developed mucoadhesive microemulsion gel could be a promising approach for brain targeting of ibuprofen through intranasal route.
\end{abstract}

Uniterms: Ibuprofen/brain-targeting. Ibuprofen/intranasal administration. Ibuprofen/mucoadhesion. Mucoadhesive microemulsion gel. Drugs/design. Transmission electron microscopy.

O objetivo deste trabalho foi planejar microemulsão/mucoaesiva em gel a fim de melhorar a captação cerebral de ibuprofeno por via intranasal. A microemulsão para mucoadesão com ibuprofeno (MMEI) foi desenvolvida pela incorporação de policarbofil como polímero mucoadesivo em microemulsão otimizada (MEI) com base em Capmul (MCM) e foi submetida à caracterização, estabilidade, mucoadesão e naso-ciliotoxicidade. A captação cerebral de ibuprofeno pela via nasal foi estudada por meio de estudo de biodistribuição em ratos albinos suíços. MEI se mostrou transparente, estável e não ciliotóxica, com $66,29 \pm 4,15 \mathrm{~nm},-20,9 \pm 3,98 \mathrm{mV}$ e $98,66 \pm 1,01 \%$, respectivamente, de tamanho médio dos glóbulos, potencial zeta e conteúdo do fármaco. O estudo revelou o estreita distribuição do tamanho dos glóbulos de MEI. Após administração intranasal única de MMEI e MEI, em dose de 2,86 mg/kg, a captação de ibuprofeno no bulbo olfativo foi em torno de 3,0 e 1,7 vezes maior, comparativamente, à injeção endovenosa de ibuprofeno (IDS). As taxas de ASC em tecido cerebral em relação ao plasma, obtidas após administração da MMEI nasal, foram, significativamente, mais elevadas do que aquelas observadas após a administração intravenosa de IDS. Os resultados do presente estudo mostraram que a microemulsão/mucoadesiva em gel poderia ser uma abordagem promissora para o direcionamento cerebral de ibuprofeno por via intranasal.

Unitermos: Ibuprofeno/captação cerebral. Ibuprofeno/administração intranasal. Ibuprofeno/mucoadesão. Microemulsão mucoadesiva/em gel. Fármacos/desenvolvimento. Microscopia de transmissão eletrônica. 


\section{INTRODUCTION}

Recently, nonsteroidal anti-inflammatory drugs (NSAIDs) appear to be protective in animal models of Parkinson's disease (PD) and regular use of NSAIDs may reduce the risk of PD in humans (Lang, Lozano, 1998, Tansey, Goldberg, 2010). Some other findings showed that NSAIDs may delay or prevent the onset of PD. Ibuprofen (2-(4-(2-methylpropyl) phenyl)propanoic acid), a NSAID used for relief of symptoms of arthritis and fever. However, the clinical usefulness of ibuprofen is limited by its high first-pass metabolism in liver, which leads to low oral bioavailability and poor brain entry due to over expression of p-glycoprotein (Chen et al., 2008). Therefore, looking for alternative routes of administration to improve therapeutic effects is necessary.

In recent years, drug delivery through nasal route has received a lot of attention, because it offers several advantages including rapid absorption of drug, avoidance of hepatic first-pass metabolism, and drug delivery preferentially to brain via the olfactory region (Woensel et al., 2013). Therefore, the nasal route to the brain may provide a better alternative to oral administration of Ibuprofen. For nasal delivery of Ibuprofen, a challenge existing in formulation development is the solubilization of poorly water-soluble Ibuprofen. Secondly effective nasal delivery volume in human is $\leq 400 \mu \mathrm{l}(200 \mu \mathrm{l}$ per nostril), hence normal solution did not provide satisfactory solubility for nasal delivery of Ibuprofen.

Microemulsions (MEs) are isotropic, thermodynamically stable transparent systems of oil, water and surfactant, frequently in combination with a cosurfactant with a droplet size usually in the range of 20$200 \mathrm{~nm}$ (Shah et al., 2014). These systems are currently of great scientific interest to the researchers because of their potential to incorporate a wide range of drug molecules (hydrophilic and hydrophobic) due to the presence of both lipophilic and hydrophilic domains (Pathak et al., 2014). Moreover, these versatile delivery systems provide protection against oxidation, enzymatic hydrolysis and improve the solubilization of lipophilic drugs and hence enhance their bioavailability (Talegaonkar et al., 2008). In addition, they are amenable for sustained and targeted delivery through oral, ophthalmic, pulmonary, vaginal, intravenous and topical routes (Ghosh, Murthy, 2006, Abdelrahim, Abdelbary, Ghorab, 2011). MEs, by virtue of their lipophilic nature and low globule size, are widely explored as a delivery system to enhance CNS uptake across nasal mucosa. Addition of mucoadhesive agent such as a polyelectrolyte polymer helps in retention of formulation in nasal cavity that further facilitates the absorption. The retention is due to the electronic interaction between mucin of nasal mucosa and the polymer (Rhee et al., 2007). Evidences of intranasal drug delivery systems formulated using mucoadhesive agent and its benefits in enhancing nose-to-brain drug transport have been reported by various scientists in the literature (Porecha et al., 2009).

Hence the objective of this investigation was to prepare, characterize and to perform comparative biodistribution study of the developed formulations in rat, and to also assess direct nose-to-brain transport. It was hypothesized that MEI / MMEI will result in effective nose-to-brain transport, enhanced rate and extent of drug transport, and greater distribution of Ibuprofen within and into the brain. This can help to maximize the therapeutic index of the drug, reduce its side effects, reduce the dose and frequency of dosing, and perhaps result into cost effectiveness (Ponchel et al., 1997; Botner, Sintov, 2011).

\section{MATERIAL AND METHODS}

\section{Material}

Ibuprofen was obtained as gift sample from Abbott India Ltd., Goa, India. Aceclofenac was procured from Alembic ltd., Baroda, India. Capmul MCM, Captex, Labrafac CC, Cremophor EL, Accenon CC and Transcutol $\mathrm{P}$ were received as gifts from ABITEC, Mumbai, India. Polycarbophil (AA-1, pharmagrade, molecular weight approximately 3.5 million) was procured as gift sample from Lubrizol Advanced Material India Pvt Ltd. (Mumbai, India). Isopropyl myristate (IPM), Oleic Acid (OA), polyethylene glycol 400 (PEG 400), PEG 600, Tween 60, Tween 80, glycerol, isopropyl alcohol, isobutyl alcohol, sodium deoxycholate, citric acid (monohydrate), disodium phosphate (dihydrate) and propranolol were purchased from Baroda Chemicals, Vadodara, India. HPLC grade sodium dihydrogen phosphate $\left(\mathrm{NaH}_{2} \mathrm{PO}_{4}\right)$, disodium hydrogen phosphate $\mathrm{Na}_{2} \mathrm{HPO}_{4}$ ), $n$-hexane, diethyl ether, $p$-phenylphenol and acetonitrile procured from Merck, India. Double distilled water was prepared by using Millipore Milli Q plus purification system.

\section{METHODS}

\section{Analytical methodology}

Ibuprofen in solubility study samples as well as in brain and blood samples was analyzed by developed reversed phase high performance liquid chromatography (RP-HPLC) method (Albert et al., 2006; Choudhary, Aroba, Sharma, 2012). HPLC analysis was performed 
using Waters 515 Series pumps combined with a Waters PDA 2998 series photo diode array detector (DAD). The column used was Agilent C18 column ( $150 \mathrm{~mm} \times 4.6$ $\mathrm{mm}$, particle size 5-micron Agilent, USA). Analysis was isocratic at $0.8 \mathrm{ml} / \mathrm{min}$ flow rate with ACN: Buffer $(0.025$ $\mathrm{M}$ potassium dihydrogen ortho phosphate) $\mathrm{pH} 4.5$ at 11:9 $\mathrm{v} / \mathrm{v}$ as mobile phase. The mobile phase was developed by mixing and filtered through a $0.2 \mu \mathrm{m}$ nylon membrane filter followed by degassing by sonication before use. The elution of drug was detected at $230 \mathrm{~nm}$.

\section{Selection of formulation components}

Selection of the oil was mainly based on the solubility of the drug. Different oils like isopropyl myristate, Capmul MCM, Labrafac CC, Oleic acid, Labrafil M 1944CS and Soyabean oil were screened for solubility study. Selection criteria for surfactant were its HLB value, drug solubility and non-toxic nature. Several surfactants like Tween-60, Tween-80, Captex-355, Accenon CC, and Cremophor EL having HLB value ranging in between 12 to 18 , were screened. Screening of co-surfactants was based on their ability to form stable and clear microemulsion at a minimum concentration and several co-surfactants like PEG 400, PEG 600, propylene glycol, glycerol, isobutyl alcohol, isopropyl alcohol and Transcutol P were screened. Excess of Ibuprofen was added to each cap vial containing $5 \mathrm{ml}$ of each of the selected vehicle. After sealing, mixtures were shaken with shaker at $37^{\circ} \mathrm{C}$ for $48 \mathrm{~h}$. After reaching equilibrium, each vial was centrifuged at $8000 \mathrm{rpm}$ for $10 \mathrm{~min}$ and excess insoluble Ibuprofen was separated by filtration using Whatman filter $(0.45 \mu)$. Both free drug as well as solubilized drug concentration was quantified by UV-VIS Spectrophotometer (Shimadzu UV1800) and mass balance was done (Vogt, Kunath, Dressman et al., 2008; Patel et al., 2010).

\section{Pseudoternary phase diagram study}

The pseudoternary phase diagrams of oil, surfactant: co-surfactant (Smix), and water were developed using distilled water titration method. The mixture of oil and at different ratio of Smix (1:0.5, 1:1, 1.5:1, 2:1, 2.5:1 and 3:1) at certain volume ratio were titrated with distilled water in drop wise manner. Using Chemix software, microemulsion regions were determined and Smix showing maximum microemulsion region was used for the development of microemulsion (Moghimipour, Anayatollah, Fatemeh, 2012; Subudhi, Mandal, 2013).

\section{Preparation of formulations}

Ibuprofen loaded microemulsion (MEI) was prepared by water titration method. Predetermined amount of Ibuprofen was dissolved in the required quantity of selected oil. Surfactant and cosurfactant concentration (Smix) from the result of pseudo-ternary phase diagrams was added to the above drug oil mixture. Finally this mixture of oil and Smix was titrated dropwise by distilled water with mild but continuous stirring until a transparent and homogenous microemulsion was produced (Patel, Mandal, Rajesh, 2012; Khan et al., 2009). Then microemulsion was formulated into microemulsion based gel (MMEI) using polycarbophil as mucoadhesive agent (Sharma et al., 2009). Ibuprofen solution (IDS, $20 \mathrm{mg} / \mathrm{mL}$ ) was prepared by addition of Ibuprofen $(200 \mathrm{mg}$ ) to $8 \mathrm{ml}$ of distilled water and ethanol (8:2) with continuous stirring. The $\mathrm{pH}$ was adjusted to $6.8 \pm 0.25$ using glacial acetic acid (approximately $0.06 \mathrm{ml} / \mathrm{ml}$ ). The mixture was stirred for $10 \mathrm{~min}$ and a clear solution was obtained. Final volume was made up to $10 \mathrm{ml}$ using distilled water (Piao et al., 2010). $\mathrm{pH}$ of the final formulation was also checked.

\section{Characterization}

\section{Characterization of microemulsion formulations}

All measurements were performed in triplicates. Optimized MEI was characterized for \% Transmittance, globule size, zeta potential, $\mathrm{pH}$ and drug content. \% Transmittance and drug content were measured by UV-VIS Spectrophotometer (Shimadzu UV1800) at $650 \mathrm{~nm}$ (Mandal et al., 2010) and $222 \mathrm{~nm}$ (Joshi et al., 2011) respectively. Globule size and zeta potential were determined by Zetasizer (Nano ZS, Malvern Instruments, UK) at a temperature of $25 \pm 2{ }^{\circ} \mathrm{C}$.

For determination of drug content, about $0.5 \mathrm{~g}$ of MMEI was weighed in a $100 \mathrm{ml}$ volumetric flask and dissolved in $50 \mathrm{~mL}$ of phosphate buffer of $\mathrm{pH}$ 7.4. The volumetric flask was kept for $2 \mathrm{~h}$ and shaken well in a shaker to mix it properly. It was diluted appropriately and analyzed on a UV-VIS Spectrophotometer (Shimadzu UV $1800)$ at $222 \mathrm{~nm}$.

For spreadability of the gel, $0.5 \mathrm{~g}$ of MMEI was placed on a glass plate within a premarked circle of $1 \mathrm{~cm}$ diameter. Over which a second glass plate was placed and a weight of $500 \mathrm{~g}$ was allowed to rest on the upper glass plate (Joshi, Patravale, 2006). Spreading of the gel with respect to the increase in the diameter after 1 min was noted.

MEI and MMEI $\mathrm{pH}$ were determined by digital $\mathrm{pH}$ meter (Systronics, India). For $\mathrm{pH}$ of the gel, $1.0 \mathrm{~g}$ of gel was dissolved in $100 \mathrm{~mL}$ of distilled water, stored for $2 \mathrm{~h}$ and then the $\mathrm{pH}$ was measured in triplicate by calibrated digital pH meter (Dhawan, Medhi, Chopra, 2009).

The viscosity of the developed MMEI was determined in triplicate at $25 \pm 1.0^{\circ} \mathrm{C}$ by Brookefield 
Viscometer (Model RVT). The sample (30 g) was placed in a beaker and was allowed to equilibrate for $5 \mathrm{~min}$ before measuring the dial reading using T-C spindle (spindle no 64 ) at 10 rpm (Joshi, Patravale, 2006; Fanun, 2010).

A drop of diluted MMEI was placed onto the surface of a copper grid coated with carbon. Upon drying, the grids with mesh size of 300 were stained with $2 \%(\mathrm{w} / \mathrm{v})$ phosphotungstic acid for $120 \mathrm{~s}$ and dried at room temperature and probed with Transmission Electron Microscopy (TEM). The process was performed at room temperature. Images were captured at the magnification of $\times 48,000$ to $\times 1,50,000$ (Chudasama et al., 2011).

\section{Nasal ciliotoxicity}

Nasal ciliotoxicity studies were carried out using excised sheep nasal mucosa. In brief, the excise nasal mucosa of sheep was exposed and treated with $1 \mathrm{~g}$ of test MMEI containing Ibuprofen at $2.86 \mathrm{mg} / \mathrm{mL}$ for $1 \mathrm{~h}$, then rinsed with saline. The mucocilia was then examined with an optical microscope (Nikon Fx-35A, Japan). Saline and propranolol (a serious nasal mucociliary toxicity agent, $1 \%(\mathrm{w} / \mathrm{v})$ solution) were used as a negative and positive control, respectively (Mandal, Mandal 2010, Mandal et al., 2010).

\section{Stability study}

Stability of the developed MMEI was carried according to ICH guideline for 6 months (Bachhav, Patravale, 2009). Optimized microemulsion was kept at cold temp $\left(4-8{ }^{\circ} \mathrm{C}\right)$, room temperature and at elevated temperature $\left(50 \pm 2{ }^{\circ} \mathrm{C}\right)$. After every 2 month for 6 months, MMEI was analyzed for phase separation, $\%$ transmittance, globule size and \% assay.

\section{Animal experiment}

All animal experiments were approved by Committee for the Purpose of Control and Supervision of Experiments on Animals (CPCSEA), Ministry of Social Justice and Empowerment, Government of India, New Delhi, India. Male Albino rats $(250 \pm 20 \mathrm{~g})$ were used for the comparative in-vivo permeation study. The animals were maintained at temperature $\left(25 \pm 2{ }^{\circ} \mathrm{C}\right)$, and humidity $(60 \pm 5 \%)$ and were supplied with food and water ad libitum. Male Albino rats weighing $250 \pm 20 \mathrm{~g}$ were anesthetized with an intraperitoneal pentobarbital injection $(40 \mathrm{mg} / \mathrm{kg})$ and kept on a heating pad to maintain the body temperature (Mandal, 2011). 35-40 $\mu \mathrm{L}$ of the developed nasal formulation containing Ibuprofen equivalent to $2.86 \mathrm{mg} / \mathrm{kg}$ were administered intranasally with the help of a micropipette $(200 \mu \mathrm{L})$ attached to low density polyethylene tubing with internal diameter 0.1 $\mathrm{mm}$ at the delivery site. For i.v. administration, $0.5 \mathrm{~mL}$ of IDS was delivered (dose equivalent to $2.86 \mathrm{mg} / \mathrm{kg}$ ) through the femoral vein (Elshafeey, Bendas, Mohamed, 2009). At 2, 5, 10, 15, 30, 60, 120, 240 and 360 min after the dose, blood was collected by cardiac puncture (Hoff, 2000; Hamza et al., 2014). Then the skull was cut open and the olfactory bulb (OB), olfactory tract (OT), cerebrum (CER) and cerebellum (CEB) were carefully excised. Each brain tissue was quickly rinsed with saline and bottled up with filter paper to get rid of blood-taint and macroscopic blood vessels as much as possible. After weighing, the brain tissue samples were homogenized with $5 \mathrm{ml}$ of saline in a tissue homogenizer (BD-144 Tissue Homogenizer, India). Blood samples were anticoagulated with heparin and centrifuged at $6000 \mathrm{rpm}$ for $10 \mathrm{~min}$ to obtain plasma. All samples, i.e. aliquots of plasma, and brain tissues homogenates, were stored for up to $48 \mathrm{~h}$ in a deep freezer $\left(-20^{\circ} \mathrm{C}\right)$ until HPLC analysis. Measurements were made using 3 rats at each time point.

\section{Analytical procedures}

Ibuprofen in plasma and brain tissue was assayed according to a modified HPLC method (Thomas, Savage, 1985; Choudhary, Arora, Sharma, 2012). Ibuprofen is extracted from plasma treated with $1.0 \mathrm{M}$ phosphoric acid for acidification using hexane and using $p$-phenylphenol as an internal standard. To $200 \mu \mathrm{L}$ plasma samples internal standard was added and was vortexing for 2 mins. Chromatographic separation achieved isocratically on a C18 column (Inertsil, $150 \mathrm{~mm} \times 4.6 \mathrm{~mm}$ ) utilizing a mobile phase of acetonitrile/phosphate buffer/water (60:30:10, $\mathrm{v} / \mathrm{v}, \mathrm{pH} 7.0$ ) at a flow rate of $1.2 \mathrm{ml} / \mathrm{min}$ with $\mathrm{UV}$ detection at $230 \mathrm{~nm} .80-400 \mu \mathrm{L}$ brain tissue homogenates, $30 \mu \mathrm{g} /$ $\mathrm{mL}$ of aceclofenac as internal standard was added and was vortexing for $2 \mathrm{~min}$. After centrifugation at 10,000 rpm for $10 \mathrm{~min}$, the drug was extracted from the supernatant by adding $0.7 \mathrm{~mL}$ of $n$-hexane and diethylether $(1: 1)$. The separated organic phases were then evaporated to dryness at $40{ }^{\circ} \mathrm{C}$. The residue was reconstituted in $100 \mu \mathrm{L}$ mobile phase and then $20 \mu \mathrm{L}$ was injected onto an HPLC system consisting of a LC-20AT VP solvent delivery system and SPD-20A UV detector (Shimadzu, Japan). In order to analyze brain tissue samples, same mobile phase i.e., $60 \%$ acetonitrile, $30 \%$ phosphate buffer and $10 \%$ water $(\mathrm{v} / \mathrm{v}, \mathrm{pH}$ 7.0 ) at a flow rate of $1.2 \mathrm{~mL} / \mathrm{min}$ was used and analyzed at $230 \mathrm{~nm}$. The retention time was $12.8 \mathrm{~min}$ for Ibuprofen and $9.2 \mathrm{~min}$ for the internal standard i.e., Aceclofenac. The linear range of Ibuprofen was 20-600 $\mathrm{ng} / \mathrm{ml}$ and 
20-1000 ng/g for plasma, and brain tissue respectively. Extraction recoveries of ibuprofen from plasma and tissue homogenates were more than $86 \%$ and $77 \%$ respectively.

\section{Statistical analysis}

All data are reported as mean $\pm \mathrm{SD}$ and the difference between the groups were tested using Student's t-test at the level of $\mathrm{P}<0.05$. More than two groups were compared using ANOVA and differences greater at $\mathrm{P}<0.05$ were considered significant.

\section{RESULTS AND DISCUSSION}

\section{Preparation and characterization of MMEI}

Since Capmul MCM is a biocompatible vehicle and has got maximum drug solubilizing capacity compared to the screened oils i.e., $62.54 \pm 1.23 \mathrm{mg} / \mathrm{mL}$, hence it was selected as oil phase. Accenon $\mathrm{CC}$ has got less drug solubilizing capacity with HLB value equals to 15.6 was selected as surfactant with the intension to provide sustained release. Results of pseudo-ternary phase diagrams were also depicted that Accenon CC as surfactant and Transcutol P as cosurfactant with Smix (3:1) were suitable for the development of microemulsion.

$\%$ Transmittance of MEI was found to $99.7 \pm 0.12$ $\%$ indicating the transparency of the system. The average globule size was $66.29 \pm 4.15 \mathrm{~nm}$ with PdI equals to
$0.183 \pm 0.19$. Moreover results of $\%$ Transmittance and average globule size as shown in Figure 1, indicates the nano size range of the formulation. PdI value indicated about monodisperse property of the formulation (Rao, Mcclements, 2011).

Average zeta potential of IME was found to be $-20.9 \pm 3.98 \mathrm{mV}$ as shown in Figure 2 indicates the stability of the formulation. This may be because moderate negative surface charges resulted neither into strong aggregation nor repulsion of the globules (Mandal, 2011).

Ibuprofen content was found to be $99.38 \pm 0.17$ $\%, 99.22 \pm 0.23 \%$ and $98.99 \pm 0.27 \%$ for MEI, MMEI and IDS respectively. $\mathrm{pH}$ of the developed formulations were around 6.4-6.8 indicating the suitability for nasal administration. No significant deviations were observed as shown in Table 1, in terms of phase separation, $\%$ transmittance, globule size and \% assay indicating that developed formulations were physical stable for 6 months at all three storage conditions and hence the formulation may be stored at room temperature. The altered storage conditions were found to have no adverse effect on the stability of the optimal formulation. TEM result as shown in Figure 3 revealed the narrow particle size distribution.

Optical microscopic results showed that there was no epithelial damage of cilia on the edge of mucosa that was treated with developed microemulsion formulations for $1 \mathrm{~h}$. This result as shown in Figure 4 [A] revealed that the developed MMEI was non-ciliotoxic and was suitable

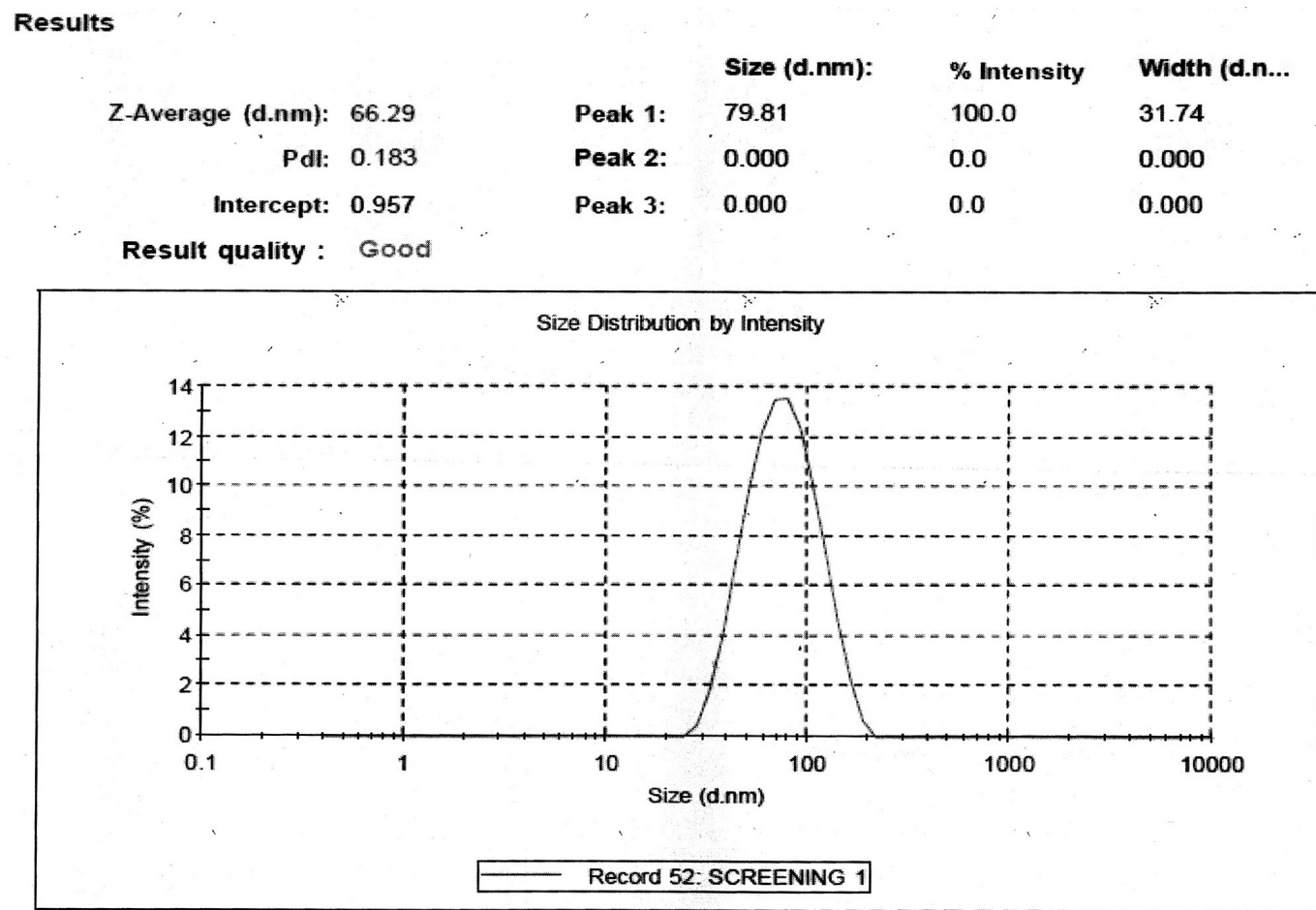

FIGURE 1 - Average globule size with PdI indicating the monodispersity of ibuprofen loaded microemulsion. 


\begin{tabular}{|c|c|c|c|c|}
\hline & & Mean $(\mathrm{mV})$ & Area (\%) & Width (mV) \\
\hline Zeta Potential (mV): $\quad-20.9$ & Peak 1: & -20.9 & 100.0 & 4.94 \\
\hline Zeta Deviation (mV): 4.94 & Peak 2: & 0.00 & 0.0 & 0.00 \\
\hline Conductivity (ms/cm): 5.02 & Peak 3: & 0.00 & 0.0 & 0.00 \\
\hline Result quality : Good & $y$ & & $x$ & \\
\hline
\end{tabular}

Zeta Potential Distribution

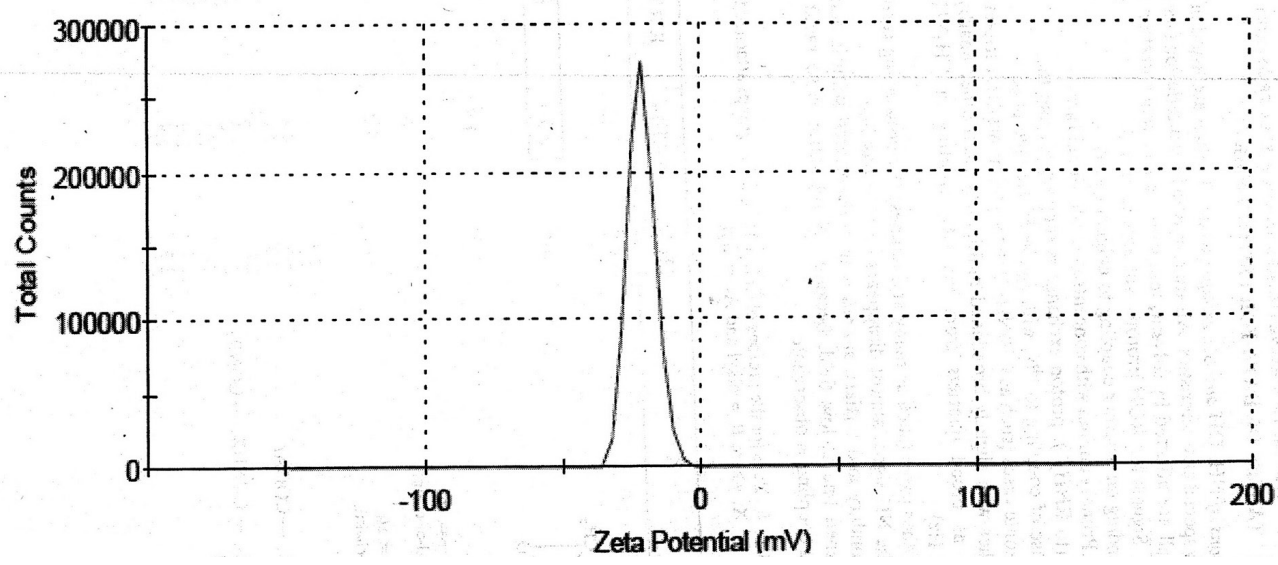

FIGURE 2 - Average zeta potential result of the optimized MEI indicating the stability of the formulation.

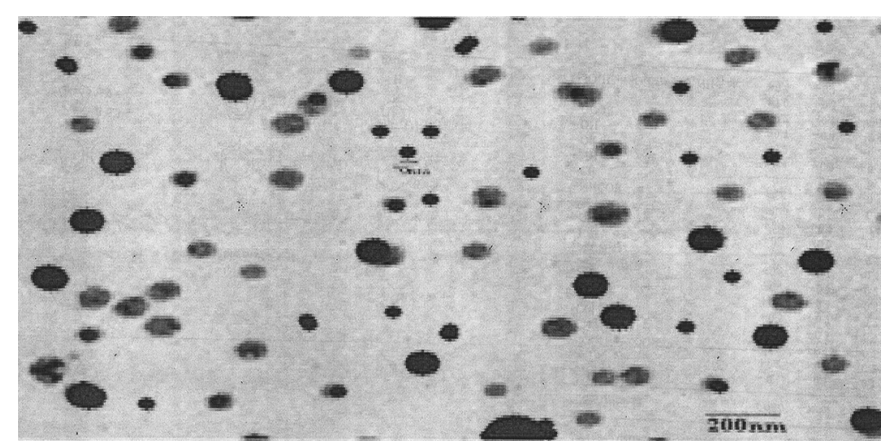

FIGURE 3 - TEM result of the optimized MEI indicating the narrow particle size distribution. for nasal application and as in Figure $4[\mathrm{C}]$ treated with saline. Formulation treated with $1 \% \mathrm{v} / \mathrm{v}$ propranolol showed severe alteration of mucosal layer as shown in Figure 4 [B].

The spreading diameter in $\mathrm{mm}$ of the prepared MMEI was found to be $56 \pm 5 \mathrm{~mm}$ after $1 \mathrm{~min}$. This spreadability result indicated that the prepared MMEI was easily spreadable by small amount of shear and hence showed excellent spreadability (Misal, Dixit, Gulkari, 2012). The drug content of the MMEI was found to be $97.44 \pm 0.71 \%$ and $\mathrm{pH}$ was found to be $6.29 \pm 0.18$, which are within the acceptable limits and suitable for
(A)

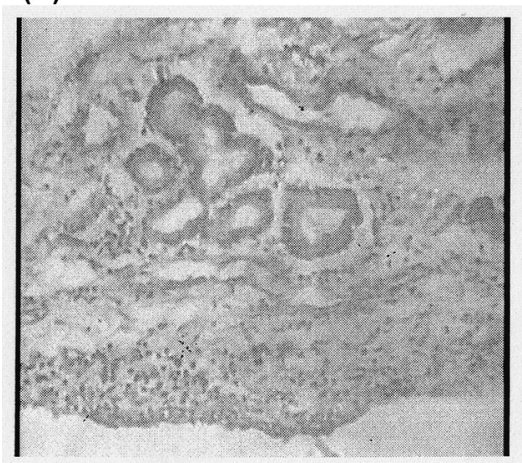

(B)

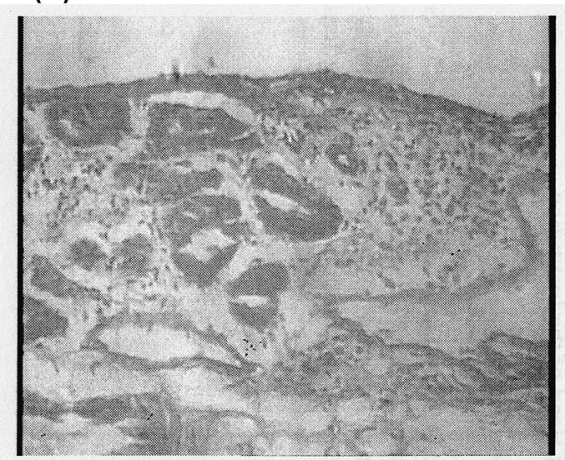

(C)

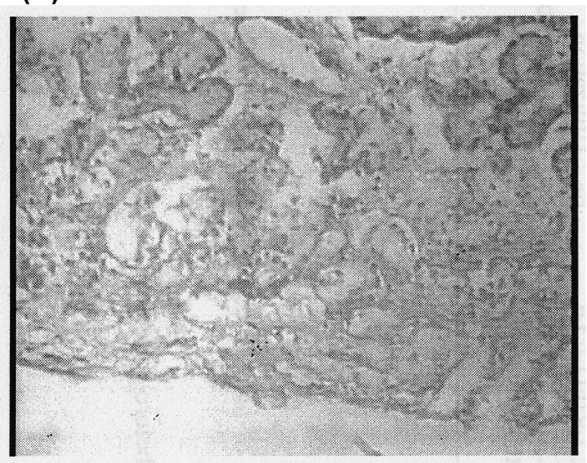

FIGURE 4 - Result of nasocilio toxicity study (A) Indicating the nontoxic property of developed MMEI on the nasal cilia. (B) Result of nasocilio toxicity study treated with propranolol showing destruction of cilia. (C) Result of nasocilio toxicity study treated with saline as negative control which shows no ciliary destruction. 
intranasal application. Viscosity of the gel was found to be $32,540 \pm 7.63 \mathrm{cPs}$ indicating the easy applicability of the formulation into the nasal cavity.

\section{Brain uptake study}

Plasma and brain tissue concentration-time profiles of ibuprofen after nasal administration of MMEI at 2.86 $\mathrm{mg} / \mathrm{kg}$ dose in rats and intravenous administration of IDS was estimated. The non-compartmental pharmacokinetic parameters were given in Table II.

Sustained absorption of Ibuprofen from MMEI into systemic circulation following intranasal delivery was observed and the maximum plasma concentration was achieved at $1 \mathrm{~h}$. The plasma levels remained constant for $3 \mathrm{~h}$. Following intravenous administration of IDS, brain Ibuprofen concentrations reached peak level at 10 min and declined fast with time. Following intranasal administration of developed MMEI, Ibuprofen level in brain displayed that maximum concentration achieved after about $30 \mathrm{~min}$ in $\mathrm{OB}$ and 60-120 min in other regions of the brain. Ibuprofen content was also differed considerably in different brain regions. The highest concentration was observed in the $\mathrm{OB}$ (the peak drug level was $1090.2 \pm 332.4 \mathrm{ng} / \mathrm{g}$ ), followed by the olfactory tract, then the cerebellum and cerebrum. These findings support the existence of a nose-brain direct pathway following the intranasal administration. As shown in Figure 5, Ibuprofen was particularly concentrated in the $\mathrm{OB}$ after nasally administered MMEI, the $\mathrm{AUC}_{0 \rightarrow 360}$ value was 2.98 times $(74569 \pm 3617 \mathrm{ng} . \mathrm{min} / \mathrm{g}$ versus $24992 \pm 1622 \mathrm{ng} . \mathrm{min} / \mathrm{g}$ ) that obtained after i.v. injection of IDS.

However, the uptakes of Ibuprofen into other brain regions after nasal dosing of MMEI were lower than those after i.v. injection as shown in Table II. This may be due to the following reason, in contrast to cerebrum and cerebellum, the mass of the $\mathrm{OB}$ is small. The distribution of Ibuprofen from OB through olfactory pathway into other brain regions could be counteracted by their large masses, thus leading to the insignificant increase in Ibuprofen content in other brain tissues (Bechgaard, Gizurarson, Hjortkjaer, 1997). In order to evaluate the brain targeting through nasal delivery of MMEI, the brain-to-plasma Ibuprofen AUC ratios at 10, 60, 360 min following both i.v. and i.n. routes were calculated. Results showed that the ratio of AUC in brain tissues to

TABLE I - Results of stability study

\begin{tabular}{lcccc}
\hline \multirow{2}{*}{ Storage condition } & \multirow{2}{*}{ Months } & \multicolumn{3}{c}{ Parameters } \\
\cline { 3 - 5 } & 2 & \% Transmittance & Particle size (nm) & \% Assay \\
\hline \multirow{2}{*}{${ }^{\circ} \mathrm{C}-8{ }^{\circ} \mathrm{C}(35 \pm 5 \% \mathrm{RH})$} & 4 & $98.4 \pm 1.1$ & $67.8 \pm 2.1$ & $98.7 \pm 1.2$ \\
& 6 & $97.1 \pm 1.3$ & $69.4 \pm 1.9$ & $97.9 \pm 0.9$ \\
& 2 & $97.4 \pm 1.8$ & $73.1 \pm 1.7$ & $97.4 \pm 1.1$ \\
\hline & 4 & $98.8 \pm 1.3$ & $62.7 \pm 1.8$ & $99.2 \pm 1.5$ \\
$\mathrm{RT}(45 \pm 5 \% \mathrm{RH})$ & 6 & $97.6 \pm 1.9$ & $72.2 \pm 2.3$ & $98.1 \pm 0.9$ \\
& 2 & $98.2 \pm 1.6$ & $65.8 \pm 1.5$ & $99.5 \pm 1.2$ \\
\hline & 4 & $98.7 \pm 1.5$ & $63.3 \pm 1.8$ & $98.8 \pm 0.7$ \\
& 6 & $97.1 \pm 0.9$ & $66.6 \pm 1.4$ & $97.9 \pm 0.9$ \\
\hline
\end{tabular}

$($ Result $=$ mean $\pm \mathrm{SD}, \mathrm{n}=3)$.

TABLE II - Pharmacokinetic parameters after intravenous and intranasal administration of IDS and MMEI respectively ( $\mathrm{n}=3$ )

\begin{tabular}{lccccc}
\hline Parameters and routes & Plasma & OB & OT & CER & CEL \\
\hline Cmax (ng/mL.g) (intranasal) & $73.4 \pm 14.4$ & $1090.2 \pm 452.4$ & $315.2 \pm 101.6$ & $157.8 \pm 19.3$ & $7164.4 \pm 9.8$ \\
Cmax (ng/mL.g) (intravenous) & $807.6 \pm 86.9$ & $2976.2 \pm 255.5$ & $3211 \pm 199.3$ & $3164 \pm 246.9$ & $3016 \pm 184.8$ \\
AUC $_{0 \rightarrow 360}$ (ng.min/mL.g) Intranasal & $23185 \pm 1330$ & $74569 \pm 3617$ & $9228 \pm 1201$ & $6829 \pm 4217$ & $5164 \pm 958$ \\
AUC $_{0 \rightarrow 360}$ (ng.min/mL.g) Intravenous & $61655 \pm 2348$ & $24992 \pm 1622$ & $13612 \pm 1016$ & $17292 \pm 627$ & $10405 \pm 1988$ \\
\% [AUCi.n. /AUCi.v.] & 37.61 & 298.37 & 67.79 & 39.49 & 49.63 \\
\hline
\end{tabular}

OB- Olfactory bulb; OT- Olfactory tract; CER-Cerebrum; CEL- Cerebellum. (Result= mean \pm SD, n =3) 


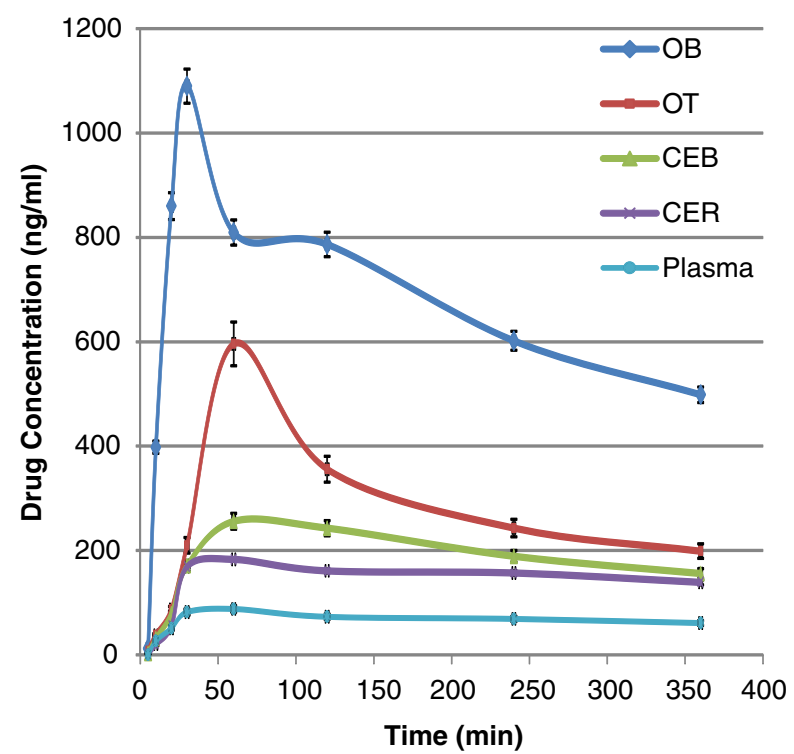

FIGURE 5 - Ibuprofen concentration in different parts of brain and blood after intranasal delivery.

that in plasma after nasal administration of MMEI were significantly higher $(P<0.05)$ than those after i.v. injection of IDS. For example, at $10 \mathrm{~min}$ after nasal dosing, the AUC ratio was 6.8 times higher than that after i.v. dosing $(19.8 \pm 2.2$ versus $3.2 \pm 0.4)$ in OB (Figure 6 A). Similarly 17.2 times $(48.8 \pm 9.2$ versus $5.31 \pm 0.81)$ and 9.4 times $(10.66 \pm 1.01$ versus $1.14 \pm 0.36)$ increment of Ibuprofen concentration in $\mathrm{OB}$ following intranasal and intravenous delivery at the time points 30 and $360 \mathrm{~min}$ as shown in Figure $6 \mathrm{~B}$ and Figure $6 \mathrm{C}$ respectively.

Following intranasal administration, about $19-86 \%$ of Ibuprofen content at $6 \mathrm{~h}$ was transported to the brain via the olfactory pathway (Botner, Sintov, 2011). In short, these results support the existence of an alternative brain entry pathway for Ibuprofen by formulating in $\mathrm{o} / \mathrm{w}$ mucoadhesive microemulsion because of its protection against enzymatic hydrolysis which may be due to the rapid drug absorption (Yang, Gao, Mitra, 2001; Bitter, Katja, Surber, 2011; Haque et al., 2012) and increasing the quantity of drug to the brain.

\section{CONCLUSION}

Results demonstrated that polycarbophil based mucoadhesive microemulsion system comprising Capmul MCM (3\% v/v), Accenon CC (26\% v/v), Transcutol P $(9 \% \mathrm{v} / \mathrm{v})$ and distilled water $(62 \% \mathrm{v} / \mathrm{v})$ was optimal for intranasal delivery of Ibuprofen. The microemulsion systems are transparent and physical stable at ambient conditions for 6 months. Results of Bioditribution study confirmed that a fraction of Ibuprofen could be transported
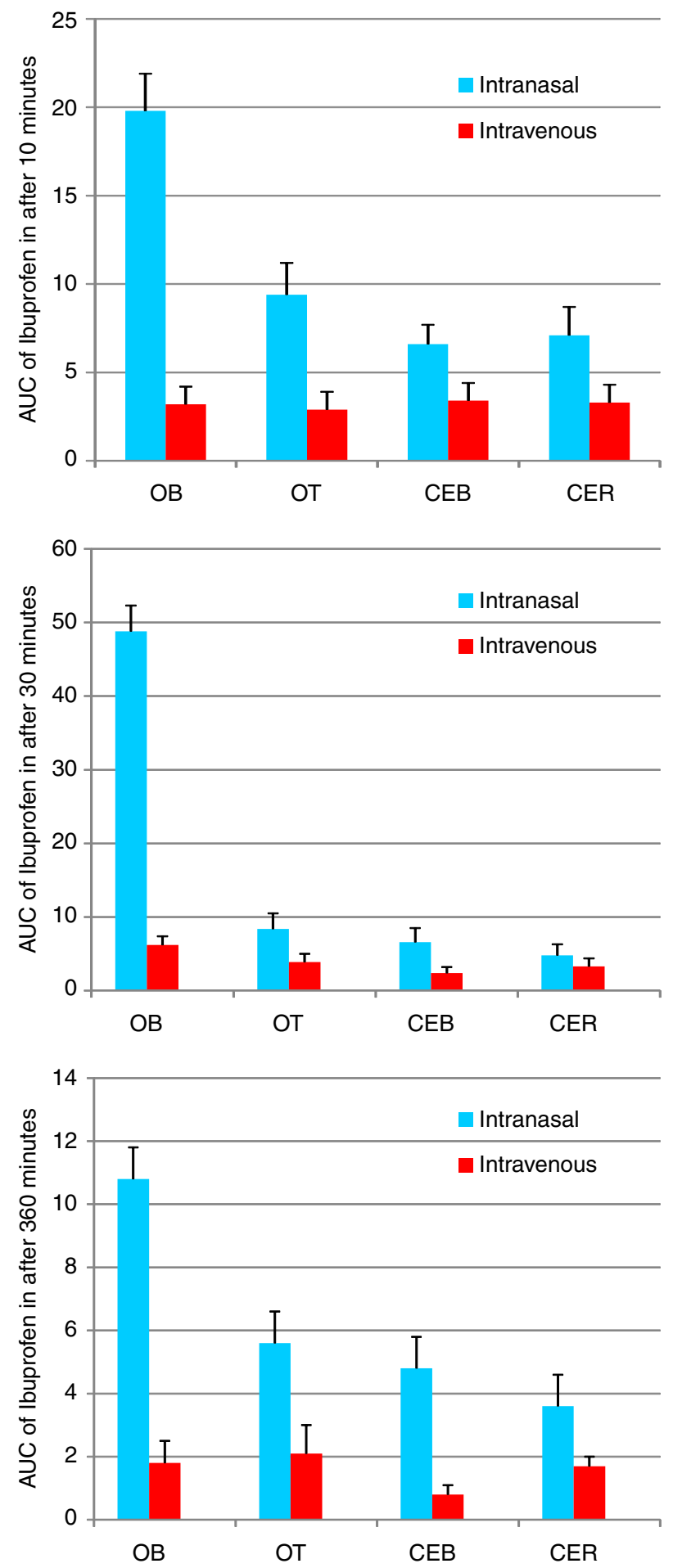

FIGURE 6 - AUC of Ibuprofen in plasma and different parts of brain after intranasal and intravenous delivery of IMME and IDS respectively $(n=3)$.

directly into the brain after nasal delivery. Enhanced rate and extent of transport of Ibuprofen following intranasal administration of MMEI may help in decreasing the dose and frequency of dosing and possibly maximize the 
therapeutic index. However, ratio of clinical benefits to the risk of the formulation developed in this investigation will decide its appropriateness in the clinical practice.

\section{ACKNOWLEDGEMENTS}

The authors are thankful to Abbott India Ltd., Goa, India and Alembic ltd., Baroda, India for providing Ibuprofen and Aceclofenac as gift sample. The authors express their gratitude to ABITECH, Mumbai, India for providing oils and surfactants as gift sample. The authors are also grateful to Mr Anand Pithadia, PIPH, Vadodara, Gujarat for providing assistance for animal study and Mrs. Kavitha Pillai for proof-reading the manuscript for grammatical and spelling errors.

\section{REFERENCES}

ABDELRAHIM, M.E.; ABDELBARY, A.; GHORAB, M. Formulation and evaluation of medicated microemulsion for topical application. Int. J. Nov. Drug. Deliv. Tech., v.1, n.4, p.208-212, 2011.

ALBERT, K.S.; RAABE, A.; GARRY, M.; ANTAL, E.J.; GILLESPIE, W.R. Determination of ibuprofen in capillary and venous plasma by high-performance liquid chromatography with ultraviolet detection. J. Pharm. Sci., v.73, n.10, p.1487-1489, 2006.

BACHHAV, Y.G.; PATRAVALE, V.B. Microemulsion-based vaginal gel of clotrimazole: formulation, in vitro evaluation, and stability studies. AAPS PharmSciTech., v.10, n.2, p.476481, 2009.

BECHGAARD, E.; GIZURARSON, S.; HJORTKJAER, R.K. Pharmacokinetic and pharmacodynamic response after intranasal administration of diazepam to rabbits. J. Pharm. Pharmacol. v.49, n. 8, p.747-750, 1997.

BITTER, C.; KATJA, S.Z., SURBER, C. Nasal drug delivery in humans. Curr. Probl. Dermatol., v. 40, p. 20-35, 2011.

BOTNER, S.; SINTOV, A.C. Intranasal delivery of two benzodiazepines, midazolam and diazepam, by a microemulsion system. Pharmacol. Pharm., v. 2, n.3, p. 180-188, 2011.
CHEN, H.; ZHANG, S.M.; HERNAN, M.A.; SCHWARZSCHILD, M.A.; WILLETT, W.C.; COLDITZ, G.A.; SPEIZER, F.E.; ASCHERIO, A. Nonsteroidal antiinflammatory drugs and the risk of parkinson disease. Arch. Neurol., v.60, n.8, p.1059-1064, 2008.

CHOUDHARY, S.; ARORA, S.; SHARMA, T. Bioanalytical method development and validation of ibuprofen using RPHPLC. Am. J. PharmTech Res., v.2, n.6, p.312-321, 2012.

CHUDASAMA, A.; PATEL, V.; NIVSARKAR, M.; VASU, $\mathrm{K}$.; SHISHOO, C. Investigation of microemulsion system for transdermal delivery of itraconazole. JAPTR, v.2, n.1, p.30-38, 2011.

DHAWAN, S.; MEDHI, B.; CHOPRA, S. Formulation and evaluation of diltiazem hydrochloride gels for the treatment of anal fissures. Sci. Pharm., v. 77, p. 465-482, 2009.

ELSHAFEEY, A.H.; BENDAS, E.R.; MOHAMED, O.H. Intranasal microemulsion of sildenafil citrate: in vitro evaluation and in vivo pharmacokinetic study in rabbits. AAPS PharmSciTech., v.10, n.2, p.361-367, 2009.

FANUN, M. Microemulsions with nonionic surfactants and mint oil. The Open Coll. Sci. J., v.3, p.9-14, 2010.

GHOSH, P.K.; MURTHY, R.S.R. Microemulsions: A potential drug delivery system. Curr. Drug. Deliv., v.3, n.2, p.167$180,2006$.

HAMZA, B.; RIHAB, O.; SAMAR, M.; EL-SHAMY, A.A. Chitosan and cyclodextrin in intranasal microemulsion for improved brain buspirone hydrochloride pharmacokinetics in rats. Carbohydr. Polym., v.99, p.297-305, 2014.

HAQUE, S.; MD, S.; FAZIL, M.; KUMAR, M.; SAHNI, J.K.; ALI, J. Venlafaxine loaded chitosan NPs for brain targeting: Pharmacokinetic and pharmacodynamic evaluation. Carbohydr. Polym., v.89, n.1, p.72-79, 2012.

HOFF, J. Methods of blood collection in the mouse. $L a b$ Animals, v.29, p.47-53, 2000.

JING, Y.; JIAN, P.Z.; QI, N.P.; YUN, L.; LIANG, C. Distribution of nobiletin chitosan-based microemulsions in brain following i.v. injection in mice. Int. J. Pharm., v.352, p.256-262, 2008. 
JOSHI, R.S.; PAWAR, N.S.; KATIYAR, S.S.; ZOPE, D.B.; SHINDE, A.T. Development and validation of UV spectrophotometric methods for simultaneous estimation of Paracetamol and Ibuprofen in pure and tablet dosage form. Pharm. Sin., v.2, n.3, p.164-171, 2011.

JOSHI, M.; PATRAVALE, V. Formulation and evaluation of nanostructured lipid carrier (NLC)-based Gel of Valdecoxib. Drug Dev. Ind. Pharm., v.32, n.8, p.911-918, 2006.

KHAN, S.; PATIL, K.; YEOLE, P.; GAIKWAD, R. Brain targeting studies on buspirone hydrochloride after intranasal administration of mucoadhesive formulation in rats. $J$. Pharm. Pharmacol., v.61, n.5, p.669-675, 2009.

LANG, A.E.; LOZANO, A.M. Parkinson's disease: first of two parts. N. Engl. J. Med., v.339, n.15, p.1044-1053, 1998.

MANDAL, S.; MANDAL, S.D.; SURTI, N.; PATEL, V.B. Development of microemulsion formulation for the solubility enhancement of flunarizine. Pharm. Lett., v.2, n.3, p.227-236, 2010.

MANDAL, S.; MANDAL, S.D. Design and development of carbamazepine mucoadhesive Microemulsion for intranasal delivery: an ex-vivo study. Int. J. Pharm. Sci. Rev. Res., v.3, n.1, p.56-60, 2010.

MANDAL, S. Microemulsion drug delivery system: design and development for oral bioavailability enhancement of lovastatin. S. Afr. Pharm. J., v.78, n.3, p.44-50, 2011.

MISAL, G.; DIXIT, G.; GULKARI, V. Formulation and evaluation of herbal gel. Indian J. Nat. Prod. Resour., v.3, n.4, p.501-505, 2012.

MOGHIMIPOUR, E.; ANAYATOLLAH, S.; FATEMEH, L. Preparation and evaluation of tretinoin microemulsion based on pseudo-ternary phase diagram. Adv. Pharm. Bull., v.2, n.2, p.141-147, 2012.

PATEL, V.; KUKADIYA, H.; MASHRU, R.; SURTI, N.; MANDAL, S. Development of microemulsion for solubility enhancement of clopidogrel. IJPR, v.9, n.4, p.327-334, 2010.

PATEL, B.M.; MANDAL, S.; RAJESH, K.S. Formulation and kinetic modeling of curcumin loaded intranasal mucoadhesive microemulsion. J. Pharm. Bioall. Sci., v.4, p.81-83, 2012. Suppl. 1.
PATHAK, R.; DASH R. P.; MISRA, M.; NIVSARKAR, M. Role of mucoadhesive polymers in enhancing delivery of nimodipine microemulsion to brain via intranasal route. Acta Pharm. Sinica B., v.4, n.2, p.151-160, 2014.

PONCHEL, M.; MONTISCI, J.; DEMBRI, A.; DURRER, C.; DUCHENE, D. Mucoadhesion of colloidal particulate systems in the gastrointestinal tract. Eur. J. Pharm. Biopharm., v.44, n.1, p.25-31, 1997.

PIAO, H.; BALAKRISHNAN, P.; CHO, H.; KIMB, H.; KIM,Y.; CHUNG, S.; SHIM, C.; KIM, D. Preparation and evaluation of fexofenadine microemulsions for intranasal delivery. Int. J. Pharm., v.395, n.1-2, p.309-316, 2010.

PORECHA, S.; SHAH, T.; JOGANI, V.; NAIK, S.; MISRA, A. Microemulsion based intranasal delivery system for treatment of Insomnia. Drug Deliv., v.16, n.3, p.128-134, 2009.

RAO, J.; MCCLEMENTS, D.J. Formation of flavor oil microemulsions, nanoemulsions and emulsions: influence of composition and preparation method. J. Agric. Food Chem., v.59, n.9, p.5026-5035, 2011.

RHEE, Y.S.; PARK, C.W.; NAM, T.Y.; SHIN, Y.S.; CHIC, S.C.; PARK, E.S. Formulation of parenteral microemulsion containing itraconazole. Arch. Pharm. Res., v.30, n.1, p.114123, 2007.

SHAH, B.M.; MISRA, M.; SHISHOO, C.J.; PADH, H. Nose to brain microemulsion-based drug delivery system of rivastigmine: formulation and ex-vivo characterization. Drug Deliv., v.45, p.89-121, 2014.

SHARMA, G.; MISHRA, A.K.; MISHRA, P.; MISRA, A. Intranasal cabergoline: pharmacokinetic and pharmacodynamic studies. AAPS PharmSciTech., v.10, n.4, p.1321-133, 2009.

SUBUDHI, B.B.; MANDAL, S. Self-microemulsifying drug delivery system: formulation and study intestinal permeability of ibuprofen in rats. J. Pharm., v.2013, p.1-7, 2013.

TALEGAONKAR, S.; AZEEM, A.; AHMAD, F.J.; KHAR, R.K.; PATHAN, S.A.; KHAN, Z.I. Microemulsions: a novel approach to enhanced drug delivery. Rec. Pat. Drug Deliv. Form., v.2, n.3, p.238-257, 2008. 
TANSEY, M.G.; GOLDBERG, M.S. Neuroinflammation in parkinson's disease: its role in neuronal death and implications for therapeutic intervention. Neurobiol. Dis., v.37, n.3, p.510-518, 2010.

THOMAS, C.J.T., SAVAGE, S. High-performance liquid chromatographic determination of ibuprofen in bulk drug and tablets. Drug Dev. Ind. Pharm., v.11, n.5, p.1123-1131, 1985.

VOGT, M.; KUNATH, K.; DRESSMAN, J.B. Dissolution enhancement of fenofibrate by micronization, cogrinding and spray-drying: comparison with commercial preparations. Eur. J. Pharm. Biopharm., v.68, n.2, p.283288, 2008.
WOENSEL, M.; WAUTHOZ, N.; ROSIERE, R.; AMIGHI, K.; MATHIEU, V.; FLORENCE, L.; GOOL, S.; VLEESCHOUWER, S. Formulations for intranasal delivery of pharmacological agents to combat brain disease: a new opportunity to tackle GBM. Cancer, v.5, n.3, p.10201048, 2013.

XUAN, Z.; XING, L.; TAO, G.; XUN, S.; ZHI-RONG, Z. In vitro and in vivo investigation of dexibuprofen derivatives for CNS delivery. Acta Pharm. Sin.. v.33, p.279-288, 2012.

YANG, C.; GAO, H.; MITRA, A.K. Chemical stability, enzymatic hydrolysis, and nasal uptake of amino acid ester prodrugs of acyclovir. J. Pharm. Sci., v.90, n.5, p.617-624, 2001.

Received for publication on $25^{\text {th }}$ November 2013 Accepted for publication on $30^{\text {th }}$ April 2015 
